\title{
The Effects of Postponing the Leagues on the Expired Contracts of the Athletes and the Trainers
}

\section{Liglerin Ertelenmesinin Sporcu ve Antrenörlerin Süresi Biten Sözleşmelerine Etkileri}

\author{
Ümit Orhan 1 iD https://orcid.org/0000-0001-7981-782X \\ Jurist, Faculty of Sport Sciences, Marmara University, Istanbul, Turkey
}

Emin Özkurt Dhttps://orcid.org/0000-0001-8684-6127

Attorney at Law, Arbitrator at CAS, EuroLeague, and QSAT

Received: April 21, 2020

DOI: 10.30655/besad.2020.27
Accepted: May 18, $2020 \quad$ Online Published: June 10, 2020

https://doi.org/10.30655/besad.2020.27

\begin{abstract}
Due to the Covid-19 outbreak caused by a virus that can be transmitted from person to person, sports activities have been stopped in the world and in our country. Postponing the league organizations brings many problems. One of these is expiration of fixed-term contracts of athletes and coaches and its effect on the transfer status. In our study, this situation was evaluated. The contract for athletes and coaches with the sports clubs is the employment contract. While athletes are excluded from the Labor Act, coaches and other sports workers are bound by the Labor Act in Turkey. Fixed-term contracts are signed with athletes and coaches. Although the contract period has expired, there may be cases where the competition schedule is extended for any reason. The first thing that comes to mind is that a competition season does not end on the date determined for reasons such as extreme bad weather, a natural disaster or terrorist attack. Some sports federations have special regulations regarding this possibility, while others do not. Many international sports organizations have the status of an association. Although the activities of these organizations occur in many states, they do not have international personalities in the face of the fact that they were established in accordance with the internal laws of certain states and states are not based on any international treaty between them. The legal basis of the sports federations in our country stems from the Codes enacted in accordance with the procedure in our constitution. In the regulations of sports federations with the agreements of athletes or coaches, it is sometimes out of the classical Law of Obligations or Labour Law doctrines. We are of the opinion that sports organizations can only make arrangements on subjects and fields of activity that cannot cause contradiction with the Codes. However, the obligation of a federation that is a member of international federations to comply with international regulations should not be ignored. A distinction should be made in regards to prolonged contracts. It can be accepted that the contract is extended in matters involving all international federations, such as the global epidemic. However, in cases where the national federations are singularly affecting by different reasons
\end{abstract}

\section{${ }^{1}$ Corresponding author: Dr. Dr. Ümit Orhan}

Marmara Üniversitesi, Spor Bilimleri Fakültesi, Cuma Yolu Caddesi, Beykoz, İstanbul umit.orhan@marmara.edu.tr 
(natural events, national epidemic, events such as terrorism), the contract should be deemed extended when the extension period is reasonable. The determination of reasonable periods for this situation by international federations will be accurate. On the other hand, short-term and short-time working allowance in Turkish Law, prohibition of termination and unpaid vacation practices can be implemented by the clubs.

Keywords: Sports law, athletes, coaches, fixed-term employment contract, Covid-19

\section{Öz}

Insandan insana kolayca bulaşabilen bir virüsün sebep olduğu Covid-19 salgını dolayısıyla dünyanın çoğunluğunda ve ülkemizde spor faaliyetleri durdurulmuştur. Lig organizasyonlarının ertelenmesi birçok sorunu da beraberinde getirmektedir. Bunlardan biri de belirli süreli sözleşmesi biten sporcu ve antrenörlerin sözleşmelerinin önceden belirlenen tarihlerde sona erip ermeyeceği ve bunun transfer durumuna etkisidir. Çalışmamızda bu durum değerlendirilmiştir. Sporcular ve antrenörler, spor kulüpleriyle yaptıkları sözleşme iş (hizmet) sözleşmesidir. Sporcular, iş Kanunu kapsamı dışında tutulmuşken, antrenörler ve diğer spor çalışanları Iş Kanunu kapsamındadır. Sporcular ve antrenörlerle belirli süreli sözleşmeler yapılmaktadır. Sözleşme süresinin bitmiş olmasına rağmen müsabaka takviminin herhangi bir nedenle uzadığı durumlarla da karşılaşılabilmektedir. ilk akla gelen, bir müsabaka sezonunun, aşırı kötü hava şartları, bir doğal afet ya da terör saldırısı gibi nedenlerle belirlenmiş olan tarihte bitmemesidir. Bazı spor federasyonlarının talimatlarında bu ihtimale ilişkin özel düzenlemeler bulunmaktayken diğerlerinde bulunmamaktadır. Pek çok uluslararası spor kuruluşu dernek statüsündedir. Bu kuruluşların faaliyetleri çok sayıda devletin ülkesini kapsamak ile birlikte belirli devletlerin iç hukuklarına göre kurulmuş olmaları ve devletlerin bu konuda aralarında yapmış oldukları herhangi bir milletlerarası antlaşmaya dayanmıyor olmaması karşııında uluslararası kişilikleri yoktur. Ülkemizdeki spor federasyonlarının hukuki temeli, Türkiye Büyük Millet Meclisi'nce Anayasamızdaki usule uygun çıkarılmış Kanunlardan kaynaklanmaktadır. Spor federasyonlarının sporcuların veya antrenörlerin sözleşmeleriyle düzenlemelerinde, zaman zaman klasik Borçlar Hukuku veya iş Hukuku öğretilerinin dışına çıkılmaktadır. Spor kuruluşlarının ancak Kanunlarla çatışmaya sebep olamayacak konularda ve faaliyet alanlarıla ilgili düzenleme yapabilecekleri kanaatindeyiz. Bununla birlikte, uluslararası federasyonlara üye olan bir federasyonun uluslararası düzenlemelere uyum sağlama yükümlülügü de göz ardı edilmemelidir. Sözleşmelerin uzamış sayılması konusunda bir ayrım yapılmalıdır. Küresel salgın gibi tüm uluslararası federasyonları ilgilendiren konularda sözleşmenin uzadığını kabul edilebilir. Ancak farklı sebeplerle (doğa olayları, ulusal salgın, terör vb olaylar) ulusal federasyonları tekil olarak etkileyen durumlarda uzama süresinin makul olduğunda sözleşme uzamış sayılmalıdır. Bu duruma yönelik makul sürelerin uluslararası federasyonlarca tespiti isabetli olacaktır. Öte yandan Türk Hukukundaki kısa çalışma ve kısa çalışma ödeneği ile fesih yasağı ve ücretsiz izin uygulamaları kulüplerce uygulanabilir.

Anahtar Kelimeler: Spor hukuku, sporcu, antrenör, belirli süreli iş sözleşmesi, Covid-19

\section{Giriş}

Covid-19 isimli virüsün yol açtığı salgın tüm dünyayı etkilemiştir. Salgın dünyada birçok sektörün faaliyetlerinin yavaşlamasına hatta durmasına neden olmuştur. Bu sektörlerden biri de spor sektörüdür. İnsandan insana kolayca bulaşabilen bir virüsün sebep olduğu salgın dolayısıyla dünyanın çoğunluğunda ve ülkemizde, amatör, profesyonel ve hatta rekreasyonel bütün spor faaliyetleri durdurulmuştur. Durdurma kararının sonucu olarak devam eden liglerin akıbeti de tartışılmaktadır. Görüşlerden biri liglerin mevcut haliyle tescil edilmesi (puan tablosunda en son oynanan maçlara göre lider şampiyon ilan edilmeli) şeklindeyken, bir diğeri bu sezonun oynanmamış kabul edilmesiyken, bir diğeri de kalan müsabakaların ileriki bir tarihte oynanıp liglerin tamamlanması yönündedir. Kanaatimizce de liglerin kalan maçlarının daha sonra bir şekilde tamamlanması daha uygundur. Önceden belirlenen kurallarla başlayan bir spor organizasyonu tamamlanmadan, o organizasyonda kural değişikliği yapılmamalıdır. Sezon başında belirlenen lig statülerinde hangi kurallar konulmuşsa, o kurallarla ligler tamamlanmalıdır. 
Dünyada birçok spor organizasyonu, müsabaka takvimlerini güncellemek zorunda kalmıştır. Örneğin futbol dalında da Avrupa Futbol Federasyonları Birliği (UEFA), kendi düzenlediği organizasyonları ertelemiş hatta Avrupa Futbol Şampiyonasını 2021'e kaydırmıştır². Öten yandan, lig organizasyonlarının ertelenmesi birçok sorunu da beraberinde getirmektedir. Bunlardan biri de belirli süreli sözleşmesi biten sporcu ve antrenörlerin sözleşmelerinin önceden belirlenen tarihlerde sona erip ermeyeceği ve bunun transfer durumuna etkisidir. Çalışmamıda bu durum değerlendirilmeye çalışılacaktır.

\section{Sporcuların ve Antrenörlerin Sözleşmelerinin Niteliği}

Sporcular ve antrenörler, spor kulüpleriyle bir sözleşme bağıyla çalışmaktadırlar. Bu sözleşme, işin görülmesi, ücret ve bağımlılık unsurlarından oluşan iş (hizmet) sözleşmesidir. Iş̧ (hizmet) sözleşmesi, işçinin işverene bağımlı olarak belirli veya belirli olmayan süreyle iş görmeyi ve işverenin de ona zamana veya yapılan işe göre ücret ödemeyi üstlendiği sözleşmedir (Bkz. TBK m.393/1 ve İş K. m.8/1). Çalışmamızda bu sözleşmeden "iş sözleşmesi" olarak bahsedilecektir.

İş Kanunu (İş K.) (Resmi Gazete, 10.6.2003, Sayı: 25134) m.1'e göre, m.4'teki istisnalar dışında kalan bütün işyerlerine, bu işyerlerinin işverenleri ile işveren vekillerine ve işçilerine faaliyet konularına bakılmaksızın uygulanır. Ancak yine aynı Kanun'da, bazı faaliyetleri, işyerlerini ve çalışanları uygulama kapsamı dışında bırakmıştır. "Istisnalar" başlıklı iş K.'nin m.4/1(g) bendi ile sporcular da isş K. kapsamı dışında tutulmuştur. Dolayısıyla sporcularla ilgili genel düzenleme Türk Borçlar Kanunu'nun (TBK) (Resmi Gazete, 4.2.2011 Sayı: 27836) hizmet sözleşmesiyle ilgili kısmıdır. Öte yandan sporcular İş K. kapsamı dışına alınmışken, antrenörler ve diğer spor çalışanları (kulüp doktoru, masör, fizik tedavi uzmanı, malzemeci) İş K. kapsamındadır ${ }^{3}$ Öğretideki görüşler de benzer yöndedir (Bkz. Akyiğit, 2016; Baştürk, 2005: Çelik, Caniklioğlu \& Canbolat, 2018; Demir, 2016; Demircioğlu \& Centel 2016; Eyrenci, Taşkent \& Ulucan, 2019; Mollamahmutoğlu, Astarlı \& Baysal, 2018; Narmanlığlu, 2014; Senyen-Kaplan 2018; Sümer, 2018; Süzek, 2018; Şakar, 2019; Tunçomağ \& Centel, 2018)

\section{Sözleşmenin Süresi}

Iş Hukukunda kural sözleşmenin belirsiz süreli yapılmasıdır. Belirli süreli iş sözleşmesi ancak Kanunda sayılmış olan şartların varlığı halinde yapılabilmektedir. İş Kanununun 11'inci maddesine göre belirli süreli işlerde veya belli bir işin tamamlanması veya belirli bir olgunun ortaya çıkması gibi objektif koşullara bağlı olarak işveren ile iş̧̧i arasında yazılı şekilde yapılan iş sözleşmesi belirli süreli iş sözleşmesidir. Bunun dışında aynı maddede belirli süreli sözleşmenin esaslı bir neden olmadıkça, birden fazla üst üste (zincirleme) yapılamayacağı, aksi halde iş sözleşmesi başlangıçtan itibaren belirsiz süreli kabul edileceği, esaslı nedenin varlığı durumunda ise zincirleme iş sözleşmelerinin belirli süreli olma özelliğini koruyacağı ifade edilmiştir. TBK m.430'a göre ise belirli süreli hizmet sözleşmesi, aksi kararlaştırımadıkça, fesih bildiriminde bulunulmasına gerek olmaksızın, sürenin bitiminde kendiliğinden sona erer. Belirli süreli sözleşme, süresinin bitiminden sonra örtülü olarak sürdürülüyorsa, belirsiz süreli sözleşmeye dönüşür. Ancak, esaslı bir sebebin varlığı hâlinde, üst üste belirli süreli hizmet sözleşmesi kurulabilir. Taraflardan her biri, on yıldan uzun süreli hizmet sözleşmesini on yıl geçtikten sonra, altı aylık fesih bildirim süresine uyarak feshedebilir. Fesih, ancak bu süreyi izleyen aybaşında hüküm ifade eder. Sözleşmenin fesih bildirimiyle sona ereceği kararlaştırılmış ve iki taraf da fesih bildiriminde bulunmamışsa, sözleşme belirsiz süreli sözleşmeye dönüşür.

\footnotetext{
${ }^{2}$ https://www.uefa.com/insideuefa/news/newsid=2641731.html, Erişim Tarihi: Mayıs 10, 2020.

3 Y.7.HD. 30.12.2014, E.2014/11411, K.2014/23332: "Sporla doğrudan uğraşan sporcunun Iş Kanunu kapsamında olmadığı, ancak doğrudan aktif spor yapmayan, sporcuyu aktif spor yapması için hazırlayan antrenör ile aktif görevi daha çok direktif vermek olan ve takımı başarıya ulaştırma görevinde bulunan teknik direktörün sporcu sayılmaması ve iş Kanunu kapsamında bir işçi olarak kabul edilmesi gerektiğinin anlaşıldığı; Benzer yönde bkz. Y.9.HD. 31.10.2017, E.2017/6606, K.2017/17044; Y.7.HD. 13.11.2014, E.2014/9899, K.2014/20785 (Legalbank, E.T. 10.04.2020).
} 
Sporcuyla ve antrenörle kulüp arasındaki iş sözleşmeleri belirli süreli iş sözleşmeleridir. Belirli süreli iş sözleşmesi için gerekli olan objektif nedenin varlığı ve belirli sözleşme yapma durumunun federasyonların talimatları (yönergeleri) ile getirilmiş olması konunun ilgi çekici tarafıdır. Öğretide sporcu - antrenör sözleşmesinin belirli süreli olmasına olanak sağlayan objektif/haklı sebebin yapılan işin teknik olarak sezonluk olması olduğu savunulmaktadır (Baştürk, 2005, 2007). Buna göre işin sezonluk olmasına ilişkin objektif koşul devam ettiği sürece belirli süreli iş sözleşmelerinin birbirini takip edecek şekilde yapılması zincirleme iş sözleşmelerinin belirsiz süreli iş sözleşmesine dönüşmesine yol açmayacaktır. Zira işin sezonluk olması objektif koşulun tükenmesine yol açmayacaktır Biz de bu hususa katılıyoruz. Nitekim Yargıtay'ın da aynı yönde kararları bulunmaktadır ${ }^{4}$. Karara göre; "antrenörlük - teknik adamlık görevleri süreklilik arz eden görevlerdendir. Bununla birlikte, çalışma ilişkisinin belirlenmesinde işin nitelik ve özelliklerinden ziyade, çalıştırılacak antrenör veya teknik adamın mesleki bilgi ve deneyiminin daha önemli olması, çalışma döneminin teknik adamın sezondaki başarısı ve performansına göre uzatılması veya sona erdirilmesi, teknik direktörlük sözleşmelerinin spor dallarındaki müsabaka sezonlarına göre belirlenip düzenlenmesini zorunlu kılmaktadır. Buna göre, antrenörlerin yaptığı iş itibariyle sezonluk çalışma hususu bizatihi objektif neden olmakta ve üst üste yapılmış olsa dahi bu özelliği değişmemektedir." Kararın isabetli olduğu fikrine katılmakla birlikte, benzer uyuşmazlıklarda antrenörün yaptığı işin niteliğinin de (profesyonel takımda mı altyapı takımında mı yoksa spor okulunda mı vb.) göz önünde tutulması gerektiği düşünmekteyiz (Orhan, 2019).

Bu sözleşme türünün belirli süreli olmasını destekleyecek unsurların başında, belirli sürenin federasyonların düzenlemelerinde yer alması da gösterilir. Örneğin futbol dalında futbolcuların sözleşmeleriyle ilgili ana prensipler Uluslararası Futbol Federasyonları Birliği'nin (FIFA, 2020) düzenlediği talimat olan Oyuncuların Statüsü ve Transferleri Hakkında Talimat (Regulations on the Status and Transfer of Players - RSTP) ile belirlenmektedir ${ }^{5}$. FIFA'ya üye futbol federasyonları da ulusal talimatlarını bu çerçevede düzenlemek zorundadırlar. Bu zorunluluk RSTP 1. maddesi üçüncü paragrafında yer alan ifadeden kaynaklanmaktadır ${ }^{6}$. Anılan paragrafa göre FIFA RSTP'nin birtakım maddeleri ulusal düzeyde bağlayıcıdır ve ulusal federasyonlar bu maddeleri herhangi bir değişiklik yapmadan, olduğu gibi, kendi talimatlarına almalıdır. Bu maddelerden biri de 18'inci maddede yer alan futbolcular ile kulüpler arasındaki sözleşmelerle ilgili özel hükümlerdir. Mesela, FIFA RSTP 18'inci maddesinin ikinci paragrafında yer alan düzenleme incelendiğinde, belirlenecek asgari sözleşme süresinin imza tarihinden itibaren sezon sonuna kadar geçerli olması yer almaktadır. Türkiye Futbol Federasyonu'nun (TFF) düzenlediği Profesyonel Futbolcuların Statüleri ve Transferleri Talimatı'na (PFSTT) göre futbolcu sözleşmesi en fazla beş yıl olarak belirlenir, 18 yaşın altındaki futbolcular ile imzalanacak olan sözleşmelerin süresi üç yıldan fazla olamaz ve her halükarda sözleşmelerin bitiş tarihinin 31 Mayıs olarak tespit edilmesi zorunludur (m.19/2 ve 3). Talimatta belirlenen sözleşme süresi FIFA RSTP'yle uyumluyken, 31 Mayıs TFF'nin tercihidir. Bu yönde bir tercih kullanılmasının sebebi de TFF tarafından her bir sezondaki müsabakanın en geç 31 Mayıs tarihinde oynanmasından gelmekte olup bu organizasyonel düzenleme FIFA RSTP ile uyumludur. Benzer şekilde Futbol Teknik Adamların Statüsü ve Çalışma Esasları Talimatı'na göre (TASÇET) de futbol antrenörlerin kulüplerle

\footnotetext{
4 Y.22.HD. 24.10.2017, E.2015/19909, K.2017/22650; benzer yönde bkz. Y.22.HD, 10.12.2014, E.2013/25882, K.2014/35076 (Legalbank, E.T. 23.10.2018):

Benzer karar için Bkz. Y.9.HD, 30.5.2017, E.2015/22032, K.2017/9342, 30.5.2017: "Mahkemece, davacının yaptığı iş itibari ile belirli süreli iş sözleşmesi yapılmasını gerektiren objektif bir neden bulunmadığı gerekçesi ile sözleşmenin baştan itibaren belirsiz süreli olduğunun kabulü ile bakiye süre ücret alacağı talebinin reddine hükmedilmiş ise de, dosya içerisindeki bilgi ve belgeler ve

özellikle Türkiye Futbol Federasyonu'nun teknik adamların statüsü ve çalışma esasları talimatnamesi dikkate alındığında; davacının teknik adam olarak çalıştığı ve iş sözleşmesinin futbol sezonu ile bağlantılı olarak süreye bağlandığı" anlaşılmaktadır. Dolayısı ile yapılan işin niteliği de dikkate alındığında sözleşmenin belirli süreli yapılmasında objektif neden bulunduğu ortadadır.

${ }^{5}$ https://www.fifa.com/who-we-are/legal/rules-and-regulations/Erişim Tarihi: Nisan 1, 2020.

${ }^{6}$ Metnin orijinali şu şekildedir: "The following provisions are binding at national level and must be included without modification in the association's regulations: articles 2-8, 10, 11, 12bis, 18, 18bis, 18ter, 19 and 19bis."

7 Bazı konular, ulusal federasyonların yetkisine bırakılmıştır. Ulusal liglerin ne zaman başlayıp biteceğine ulusal federasyonlar karar verir. Rusya gibi bazı ülkelerde sezon planlaması kış şartlarına göre yapılmaktadır. Bunun gibi bazı federasyonlar da sözleşmelerin bitiş tarihi olarak 30 Haziran'ı tercih edebilmektedir.
} 
yapacakları sözleşme süresinin üst sınıı bulunmamakla beraber, m.11/3'e göre "her halükarda sözleşmelerin bitiş tarihinin 31 Mayıs olarak tespit edilmesi zorunludur." denmektedir. Basketbol dalında da "Sözleşmeli Basketbolcular Lisans, Tescil ve Transfer Talimatı (SBLTTT)" m.21/1/c.1'e göre bütün tek tip sözleşmeler en fazla beş yıl süreli olabilir. Aynı maddenin z'nci fıkrasına göre, "sözleşmelerin bitiş tarihlerinin erkek liglerinde 30 Haziran, kadın liglerinde ise 31 Mayıs olarak tespit edilmesi zorunludur." Yine basketbol dalında. Sözleşmeli Basketbol Antrenörleri Çalışma Usul ve Esasları Talimatı'nda ise antrenörlerin sözleşmelerinin asgari süresinin üç ay olacağı (m.5) ancak en fazla beş yıl süreli olabileceği belirtilmiş, sözleşmelerin sona erme tarihlerinin ise 30 Haziran olarak tespiti zorunlu tutulmuştur (m.12/1). Voleybol dalında Sporcu Tescil, Lisans ve Transfer Talimatı m.24/4'e göre Türkiye Sultanlar / Efeler Ligi ve 1'inci Liglerinde yer alan kulüpler, sporcuları ile en fazla 5 yıllık sözleşme yapabilirler. Sözleşmelerin sona eriş tarihlerinin yerli oyuncular için $31 \mathrm{Mayıs,} \mathrm{yabancı}$ oyuncular için transfer sertifikasında belirtilen süre olarak tespit edilmesi zorunludur. Voleybolda antrenörlerin sözleşmelerine ilişkin ayrı bir talimat bulunmamaktadır.

5984 sayılı TFF'nin Kuruluş ve Görevleri Hakkındaki Kanun'da, TFF'nin FIFA ve UEFA'nın düzenlemelerine uymak zorunda olduğu hükme bağlamışır ${ }^{9}$. Keza aynı husus diğer spor dalları için de söylenebilir. 3289 sayılı Kanunun bağımsız spor federasyonlarla ilgili Ek g'uncu maddesine göre "Spor dalı ile ilgili faaliyetleri ulusal ve uluslararası kurallara göre yürütmek..(ile) görevli ve yetkili..('dir)" (m.Ekg/1, c.1). Dolayısıyla uluslararası federasyonların düzenlemeleri ve 5984 ve 3289 sayılı Kanunlardaki TFF'nin ve diğer bağımsız spor federasyonlarının bu kurallara uyma zorunluluğuna işaret eden ifadelerle; belirli süreli sözleşme yapılması için gereken objektif koşulun Kanun'dan kaynaklandığı kanaatindeyiz.

\section{Sözleşmenin Süresinin Uzamış Sayılması}

Sözleşme süresinin bitmiş olmasına rağmen müsabaka takviminin herhangi bir nedenle uzadığı durumlarla da karşılaşılabilmektedir. Örneğin TFF 2014 - 2015 Futbol Sezonunda Galatasaray ile Bursaspor arasında oynanan Türkiye Kupası final maçı, 31 Mayıs'tan sonraki bir tarihte, 03.06.2015 tarihinde oynanmıştır ${ }^{10}$. Aslında bu durum istisnaidir. Illk akla gelen, bir müsabaka sezonunun, aşırı kötü hava şartları, bir doğal afet ya da terör saldırısı gibi nedenlerle belirlenmiş olan tarihte bitmemesidir.

Bazı spor federasyonlarının talimatlarında bu intimale ilişkin özel düzenlemeler bulunmaktadır. Örneğin TFF'nin yukarıda zikredilen talimatlarında böyle hükümler bulunmaktadır ${ }^{11}$. PFSTT'na göre sözleşme bitiş tarihinden sonra resmi müsabakaların devam etmesi halinde, sözleşmenin süresi müsabakaların bitimine kadar uzamış sayılır (m.19/3/c.2). Aynı hüküm antrenörlerle ilgili TASÇET m.11/2'de aynı şekilde tekrarlanmıştır. TFF'nin düzenlemelerine göre böyle bir durumda futbolcuların

\footnotetext{
${ }^{8}$ Aynı husus yine aynı Talimatın 27'nci maddesinde tekrarlanmıştır.

${ }^{9} 5984$ sayılı Kanun m.3 - (1) TFF'nin görevleri şunlardır: ...

c) FIFA ve UEFA'nın yetkili organları tarafından konulan kuralların gereği gibi uygulanmasını sağlamak, ulusal talimatlar hazırlamak ve Türkiye'yi futbol ile ilgili konularda yurt dışında temsil etmek...

f) Üyelerinin, kulüplerin, futbolcuların, hakemlerin, yöneticilerin, teknik direktör ve antrenörlerin, sağlık personelleri, futbolcu temsilcileri ve müsabaka organizatörleri ile diğer tüm ilgililerin FIFA, UEFA ve TFF tarafından konulan Statü, talimat ve düzenlemeleri ile bunların yetkili kurulları tarafından verilen kararlara uymalarını sağlamak...

(2) TFF'nin teşkilat, görev ve yetkileri, teşkilatın çalışma usul ve esasları, oluşturulacak diğer kurul ve birimler, merkez, yurt içi ve yurt dışı teşkilat birimlerinin görevleri ile bu Kanunun uygulanmasına dair diğer hususlar; TFF'nin üyesi bulunduğu FIFA ve UEFA kurallarına uygun olarak, Genel Kurulun yapacağı ve Resmi Gazete'de yayımlanarak yürürlüğe girecek TFF Statüsü ile Yönetim Kurulunun yapacağı ve aksi kararlaştırılmadığı sürece TFF'nin resmi internet sitesinde yayımlandığı gün yürürlüğe girecek talimatlarla belirlenir.

${ }^{10}$ http://www.tff.org/Default.aspx?pageld=29\&macld=139946, Erişim Tarihi: Nisan 6, 2020.

${ }^{11}$ Basketbol dalında ise sözleşme bitiş tarihinin sezon ortasına gelmesi durumunda süre 30 Haziran tarihine uzar (SBAÇEUT m.12/1). Aynı talimatın 20'nci maddesine göre de Sözleşme süresi içinde, antrenörlerin kusurlarından dolayı bir sezon içinde altı (6) aydan fazla hak mahrumiyet cezası alması durumunda, kulübün isteği halinde, antrenörün sözleşme süresi aynı oranda uzar. Dondurulan sözleşme yeniden yürürlük kazandığında süre eklemesi sonucu bitiş tarihi senenin ortasına denk gelirse, sözleşmenin bitiş tarihi o sezonun 30 Haziran tarihine kadar uzatılır.
} 
ve antrenörlerin kulüplerle olan sözleşmeleri talimatlardaki genel sona erme tarihi olan 31 Mayıs'ta değil, en son müsabaka ne zaman yapılırsa o zaman sona ermiş sayılacaktır.

Bu yönde bir düzenleme olması, aslında "sezon" tanımından ileri gelmektedir. PFSTT'de yer alan tanıma göre, FIFA RSTP ile aynı doğrultuda olarak, sezon kelimesi "ilk resmi müsabaka ile son resmi müsabakanın oynandığı tarihler arasındaki süreyi" ifade etmektedir. TFF tarafından sözleşmenin sona ereceği sürenin belirlenip bu yönde bir uzama hükmü konulmaması halinde, bu durum FIFA RSTP zorunlu hükümleri ile çatışabilecektir.

Burada bir paragraf daha açıp. FIFA tarafından uygulamaya konulan yeni kural ve tavsiyelerden bahsetmek gerekir ${ }^{12}$. Yukarıda açıkladığımız üzere, FIFA RSTP 18. maddesi ulusal federasyonların herhangi bir değişiklik yapmadan olduğu gibi benimsemek zorunda olduğu maddelerden biridir. FIFA da, yayınlamış olduğu Covid-19 kılavuzunda, önerilen rehber prensip olarak, sözleşmelerin yeni tespit edilecek sezon sonu tarihine kadar uzaması yönünde görüş bildirmiştir. Bu durumda sözleşmenin aynı şartlarla ve erteleme süresince uzadığı kabul edilmelidir. Futbolda durum yukarıdaki paragraftaki gibiyken, diğer spor dallarında ise müsabaka takviminin uzaması haline ilişkin özel bir düzenleme bulunmamaktadır. Hatta basketbolda SBLTTT m.14'e göre "sözleşmeli Türk vatandaşı basketbolcular, sözleşme sürelerinin bitiminde herhangi bir bonservis bedeli ödemeksizin istedikleri kulübe transfer yapabilirler" hükmü mevcuttur. Bu durumda hukukun genel kurallarına başvurmak gerekir. Burada esasen tartışııması gereken konular; federasyon düzenlemeleri ile Kanunların ilişkisi ve şayet sözleşmenin süresi uzamış sayılırsa hangi şartlarla uzamış sayılacağıdır.

\section{Spor Federasyonlarının Düzenlemeleri ile Kanunların İlişkisi}

Spor federasyonlarının düzenlemeleri ile tabi oldukları devletlerin çıkardıkları kanunların ilişkisine geçmeden önce bu yapıların hukuki niteliklerini açıklamak isabetli olacaktır. Pek çok uluslararası spor kuruluşu (IOC, FIFA, UEFA, FIBA, FIVB) İsviçre'de mukim birer dernek statüsündedir. Bu kuruluşların faaliyetleri çok sayıda devletin ülkesini kapsamakla birlikte, belirli devletlerin iç hukuklarına göre kurulmuş olmaları ve devletlerin bu konuda aralarında yapmış oldukları herhangi bir milletlerarası antlaşmaya dayanmıyor olmaması karşısında uluslararası kişilikleri yoktur. Devletlerin bazı uluslararası spor kuruluşlarına tolerans göstermeleri buna zorunlu olduklarına dair bir inançtan değil, spora bakış açıları kaynaklıdır (Baykal, 2007).

Uluslararası ve ulusal spor federasyonlarının uluslararası sözleşme yapma yetkileri bulunmadığı gibi herhangi bir yasama (kanun yapma) kudretleri de bulunmamaktadır. Genellikle koydukları kurallara uymasının sebebi; o spor dalının paydaşlarının (kulüplerin ve sporcuların), tescilleri sırasında söz konusu kuruluşların düzenlerine uyacaklarına dair verdikleri taahhütlerdir. Aynı şekilde ülkemizdeki spor federasyonlarının hukuki temeli, kendilerinden değil, yasama organı Türkiye Büyük Millet Meclisi'nce anayasamızdaki usule uygun çıkarılmış Kanunlardan kaynaklanmaktadır (5894 ve 3289 sayılı Kanunlar).

Spor federasyonlarının sporcuların veya antrenörlerin sözleşmeleriyle düzenlemelerinde, zaman zaman klasik Borçlar Hukuku veya iss Hukuku öğretilerinin dışına çıkılmaktadır ${ }^{13}$. Buradaki düzenlemelerin, hiyerarşik olarak kendilerinden üstte bulunan normlara aykırı düzenlemeler içeremeyeceği kanaatindeyiz. Ast kuralın üst kurala aykırı olamamasını gerekli kılan normlar

\footnotetext{
12 https://img.fifa.com/image/upload/zyqtt4bxgupp6pshcrtg.pdf Erişim Tarihi: Nisan 13, 2020

${ }^{13}$ Sporcunun uyuşmazlıkla alakalı ilgili ilk olarak federasyona başvurma zorunluluğu buna örnek olarak verilebilir. Basketbol ve voleybol dallarında sözleşmeye dayanan uyuşmazlıkla ilgili olarak ilk önce ilgili Federasyonun Yönetim Kurullarına başvurma zorunluluğu vardır. Örneğin; Türkiye Voleybol Federasyonu Sporcu Tescil, Lisans ve Transfer Talimatı 39'uncu maddeye göre "Fesih hakkını kullanmak isteyen taraf, noter kanalıyla karşı tarafa ihtarname keşide etmek ve bunun bir örneğini Federasyona göndermek mecburiyetindedir. Bu tebligata rağmen 10 gün içinde sözleşme hükümleri yerine getirilmez ya da eksik yerine getirilirse sporcu serbest kalabilir. Bu konuda ilgilinin talebi üzerine verilecek Federasyon Yönetim Kurulu kararı kesindir. Sözleşmesini fesihte Federasyon tarafından haklı görülen sporcu, ilk transfer döneminde dilediği kulüple hiçbir şart aranmaksızın sözleşme imzalayabilir." Aynı hususta benzer hükümlere Türkiye Basketbol Federasyonu Sözleşmeli Sporcular, Lisans, Tescil ve Transfer Talimatının 31'inci, 32'nci, 33'üncü ve 34'üncü maddelerinde de yer verilmiştir.
} 
hiyerarşisi, bir başka açıdan anayasanın üstünlüğünü ve bağlayıcılığı ilkesinin bir devamı niteliğindedir (Esener, 2008; Deryal, 2011). Spor federasyonlarının kuralları yalnızca sportif düzenle alakalı olmalıdır (oyun kuralları, müsabaka statüleri, kulüplerin ya da sporcuların federasyonların düzenlediği müsabakalara katıım hakkı vb). Örneğin bir sporcu sözleşmesinde feshin geçerlilik şartlarına, feshin geçerli olup olmadığına karar verememelidirler. Fesih, bozucu yenilik doğuran bir haktır ve karşı tarafa ulaşmakla hüküm doğurur (Antalya \& Topuz, 2019; Baycık, 2011). Federasyonlar, yönetim kurullarının hazırladıkları talimatlara koydukları hükümlerle bu temel hukuk kaidesini bertaraf edemezler (Orhan, 2018). Fesih konusunda taraflardan istenen bildirim sadece sportif düzeni takip için gerekli olan bilgidir ki bu sayede hangi sporcu veya teknik adamın hangi kulüple ilişkisi devam ediyor ya da hangi tarafa sportif yaptırım uygulanabilecek bilinsin.

Aynı hususta 5984 sayılı TFF Kanunu'nun bir maddesinden de değerlendirmek gerekir. Kanunun "Türkiye Futbol Federasyonunun Görevleri" başlıklı 3'üncü maddesinin 1/a bendine göre TFF'nin görevlerinden biri de Türkiye'deki her türlü futbol faaliyetini yürütmek, düzenlemek ve denetlemektir. Acaba bu Kanun maddesi TFF'nin futbolla ilgili her türlü konuda düzenleme yapmasına cevaz verir mi? Kanunla kurulan idari kuruluşların çoğunda benzer ifadelere rastlanabilmektedir. Böyle genel bir ifadeden bu kadar kapsamlı bir yetki çıkarılması beklenemez. 3289 sayılı Kanunda diğer spor federasyonları ile ilgili benzer bir ifade bulunmadığını da ifade edelim.

Sonuç olarak, spor kuruluşlarının ancak Kanunlarla çatışmaya sebep olamayacak konularda ve faaliyet alanlarıyla ilgili düzenleme yapabilecekleri kanaatindeyiz. Bunun sonucu olarak, taraflardan biri, talimata değil de yürürlükteki bir Kanuna uygun hareket ettiğinde, Kanunun emrettiği üstün tutulmalıdır. Örneğin bir sporcu, sözleşmeyi haklı nedenle feshederken, federasyon talimatlarındaki sürelere uymayıp TBK m.435'teki derhal feshi uygulasa ve bu husus yargılama konusu olsa, sporcunun yaptığı hukuka uygun sayılmalıdır. Özetle kuralın uygulanması konusunda çatışma varsa spor federasyonunun çıkardığı talimat değil Kanun hükmü uygulanmalıdır. Ancak altını çizerek belirtmemiz gerekir ki buradaki tespitimiz durumun ulusal yargı organlarına (örn. Türk mahkemelerine) sirayet edeceği durumlarla ilgilidir. Genellikle uluslararası transferlerde ve sözleşmelerle farklı tahkim organlarının görevli kılındığı yargılamalara ilişkindir. Böyle durumda genellikle uluslararası spor federasyonlarının düzenlemeleri ve ilgili tahkim organının içtihatları geçerli olacaktır.

\section{Uzatılan Sözleşme Süresi}

Türk Borçlar Kanunu (m.430/1) ve iş̧ Hukuku öğretisinde, belirli süreli iş sözleşmesinin süresinin dolması, aksi kararlaştırımadıkça sözleşmenin kendiliğinden sona erme halidir (Bkz. Çelik ve diğerleri, 2018; Eyrenci ve diğerleri, 2019; Narmanlıoğlu; 2014; Senyen-Kaplan, 2018; Tunçomağ ve Centel, 2018; Süzek, 2018). Sözleşmenin sona ereceği tarih, spor federasyonlarının düzenlemelerindeki gibi net bir takvim birimi ise, kural olarak sözleşme o tarihte sona ermiş sayılır. Böyle durumda tarafların ayrıca bir bildirimde bulunmaları da beklenmez. Ancak mevzuatımızda Deniz İş Kanununda (Resmi Gazete, 29.04.1967. Sayl: 12586) özel bir düzenlemeye yer verildiği görülmektedir. Kanunun m. 7/II hükmüne göre, "Belirli sefer için yapılmış hizmet akti, akitte yazılı seferin sonunda geminin vardığı limanda yükünü boşaltmasıyla sona erer." Deniz iş̧ Kanununda böyle özel bir düzenlemeye yer verilmesi bu kanuna tabi çalışmaların özelliğinden kaynaklanmaktadır (Bozkurt Gümrükçüoğlu, 2012).

Kanaatimizce bu özellikli çalışma halinden sporcular için de bahsedilebilir. Zaten belirlenen takvim biriminden kasıt da o spor dalının müsabaka sezonuna ilişkindir. Aslında takvim birimi değil sezon süresi gözetilerek ilgili takvim birimleri düzenlemelere eklenmiştir. Bu şekilde düşünüldüğünde sezonun makul bir süre için uzaması mevcut sözleşmenin de o süre boyunca uzamış sayılmasını gerektirir. Ancak şu intimalleri de değerlendirmek gerekir. Örneğin bir spor ligi, Türkiye'ye has bir sebeple sözleşmede kararlaştırımış tarihte değil de diğer ülkelerin yeni sezonlarının başlayacağı zamana uzasa, bu takdirde diğer ülkelere transferi söz konusu olan sporcu için makul bir uzamadan bahsedilemez. Ancak şu anda neredeyse Dünyada tüm ligler ertelendiği için burada makul bir uzamadan bahsedilebilir. Özetle kanımızca mevcut Covid-19 salgını sebebiyle sözleşmelerin sürelerinin sezon tamamlanana kadar uzamış sayılması makuldür. Süresi uzayan sözleşmeler de yeni 
bir sözleşme değil, eski sözleşmenin devamıdır. Sezon tamama erene kadar mevcut sözleşme geçerliliğini sürdürür.

Durumu futbol açısından değerlendirecek olursak, FIFA tarafından uygulamaya konulan yeni kural ve tavsiyelerde, yapılacak değişiklikler için belirli kıstaslar belirlenmiştir. Covid-19'un anlaşmaları askıya alması ve taraflar üzerinde yarattığı baskı düşünüldüğünde, teknik direktörler ve oyuncular yükümlülüklerini yerine getirememekte, kulüpler de faaliyetlerini askıya almaktadır. Bu dönemde, kulüplerin yıkımına sebep olmadan teknik direktör ve oyunculara belirli bir maaş ödemesinin sağlanması için önerilen tavsiye prensipler yer almaktadır. Buna göre FIFA, kulüpler ve çalışanlarının bir araya gelerek yeni şartları görüşmesini teşvik etmektedir. Yapılacak görüşmelerde belirlenmesi gereken hususlar; ücret ve yan menfaatler, hükümet yardım programları, sözleşme uzamasındaki koşul ve şartlardır. FIFA bu hususta, ilgili çalışanıyla görüşme gerçekleştirmeye çalışıp çalışmadığı, kulübün ekonomik durumu, yeni koşulların ölçülülüğü, ücret değişikliği sonucunda çalışanların alacağı net ücreti, bu kararın tüm kadroya mı uygulandığı yoksa belirli bir kısım çalışanlar mı uygulandığı durumlarını inceleyecektir. Bununla birlikte TFF de sözleşmelere iliş̧kin tavsiye kararını 09.05.2020 tarihinde internet sitesinden duyurmuştur Gerek FIFA'nın gerekse TFF'nin sözleşmeler konusundaki duyuruları bağlayıcı değil tavsiye niteliğindedir.

Belirtmek gerekir ki dünya çapında bir salgın intimali şu ana kadar hiçbir spor federasyonunun düzenlemelerinde gözetilmemiştir. Buna benzer durumları ifade etmek için kullanılan mücbir sebep kavramı daha çok sözleşmenin bir tarafın başına geldiğinde diğer tarafın fesih hakkıyla ilgilidir. Ancak bu defa durum öngörülmüş düzenlemelerden farklıdır. Çünkü buradaki mücbir sebep sözleşmelerin tüm taraflarını alakadar etmektedir. Yani sporcu bir kulüpten ayrılsa gidip hizmetini görebileceği başka bir kulüp de yoktur. Uluslararası spor federasyonları da tavsiye kararlarıyla sonucu yürütmeye çalışmaktadır. Müsabaka takvimlerinin, dünya çapında benzer tarihlere göre ayarlanması tüm sporcu ve antrenörler için isabetli olacaktır. Örneğin mevcut sezonların aynı zaman diliminde tamamlanıp, yeni sezonların benzer takvime ayarlanması durumunda tarafların mağduriyeti azalacaktır.

Yukarıda bahsetmiş olduğumuz FIFA tarafından uygulamaya konulan yeni kural ve tavsiyeler çerçevesinde, erteleme sebebiyle sezonların ve/veya tescil dönemlerinin çakışması halinde, aksi kararlaştırılmadığı sürece, oyuncuların başka bir takıma transfer olmasında dahi liglerin bütünlüğü ve sağlamlığını sağlamak için öncelik eski takımına verilecektir. Bir diğer ifadeyle, bir oyuncunun başka bir takıma transfer olmasından sonra mevcut sezonun tamamlama maçlarının oynanması halinde, ilgili oyuncu eski kulübünde müsabakalara çıkabilecektir.

Sözleşmelerin benzer durumlarda uzamış sayılmasıyla ilgili uluslararası spor federasyonlarının "makul süreyi" belirlemeleri gelecekteki benzer durumlar açısından isabetli olacaktır. Kanaatimizce bu süre sezonun bitiminden itibaren 20 gün veya 30 gün olarak belirlenebilir. Çünkü her uzama sebebi Covid-19 gibi küresel bir olaya dayanmayabilir. Bu konuyu bir örnekle açıklamak yerinde olacaktır. Örneğin birçok ülkede ligler Mayıs sonunda bitmekte ve Haziran sonuna doğru takımlar yeni sezon hazırlıklarına başlamaktadırlar. Sezon ortasında (Ocak 2021'de) 2021-2022 sezonu için Türkiye'de bir takımla sözleşme imzalayan Brezilyalı futbolcu A, lisansının bulunduğu Portekiz Ligine salgın hastalık sebebiyle 3 ay ara verildiği için Haziran 2021 sonu yeni takımının kampına katılamayacak, Portekiz'deki ligin Temmuz sonunda tamamlanmasını bekleyecek, o lig bittikten sonra yeni takımına katılacaktır. Dolayısıyla yeni takımıyla sezon öncesi kampı kaçıracak, uyum sürecini geciktirecek, gerekli dinlenmeyi de yapamayacaktır. Hâlbuki FIFA makul süre konusunda bir düzenleme yapmış olsa bu durumda futbolcu makul süre boyunca bekleyecek, süre sonunda yeni takımına katılabilecektir. Kulüpler de bu durumda buna göre hazırlıklarını yapacak, gerektiğinde A takıma katılacak altyapı oyuncularını hazır tutacaktır.

$\mathrm{Bu}$ yaşanan tecrübeden sonra kulüplerin sporcularla yapacakları sözleşmelere sezonların uzaması intimaline karşıık özel düzenleme yapacaklarını gözetmek gerekir. Böyle bir sözleşme maddesinin geçerli sayılması ve tarafları bağlayacağını düşünüyoruz. Bu takdirde benzer sebeplerle lig uzarsa futbolcu sözleşmesine sadık kalarak süreyi (sezonu) tamamlayacaktır. 


\section{Uzatılan Sözleşmelere İş Hukukundaki Bazı Uygulamaların ve Güncel Değişikliklerin Etkisi}

Son dönemde Covid-19 salgını nedeniyle, Türk iş̧ Hukukunu doğrudan etkileyen bazı kanuni değişiklikler yapılmıştır. Bu hususta 7726 sayılı "Bazı Kanunlarda Değişiklik Yapılmasına Dair Kanun (Resmi Gazete, 26.03.2020, Sayı:31080 Mükerrer)" ve 7244 sayılı "Yeni Koronavirüs (Covid-19) Salgınının Ekonomik ve Sosyal Hayata Etkilerinin Azaltılması Hakkında Kanun ile Bazı Kanunlarda Değişiklik Yapılmasına Dair Kanunda (Resmi Gazete, 17.04.2020, Sayı: 31102)" yer alan ve konumuzla alakalı değişikliklerin etkilerinden bahsetmek isabetli olacaktır.

\section{Kısa Çalışma Ödeneği Uygulaması}

Covid-19 salgını ile kısa çalışma uygulaması, işverenlerce eskiye göre daha fazla rağbet edilen bir uygulama haline gelmiştir. Kanuna göre kısa çalışma, "genel ekonomik, sektörel veya bölgesel kriz ile zorlayıcı sebeplerle işyerindeki haftalık çalışma sürelerinin geçici olarak önemli ölçüde azaltılması veya işyerinde faaliyetin tamamen veya kısmen geçici olarak durdurulması hallerinde, işyerinde üç ayı aşmamak üzere kısa çalışma yapılabilir" (4447 sayılı Kanun Ek m.2/1). Son kanuni değişikliklerle ve yeni maddelerle birlikte kısa çalışmayla ilgili de birtakım değişiklikler yapılmışıır ${ }^{14}$. Konumuzla alakalı olarak burada, kulüplerin kısa çalışma ödeneğinden yararlanıp yararlanamayacağı ve bunun uzayan sözleşmelere etkisini değerlendirmeye çalışılacaktır. Kısa Çalışma ve Kısa Çalışma Ödeneği Hakkında Yönetmeliğin (Resmî Gazete 30.04.2011, Sayı: 27920) 6'ncı maddesine göre işçinin kısa çalışma ödeneğinden yararlanabilmesi için: (a) İşverenin kısa çalışma talebinin uygun bulunması; (b) İşçinin kısa çalışmanın başladığı tarihte, 4447 sayılı Kanunun 50'nci maddesine göre çalışma süreleri ve işsizlik sigortası primi ödeme gün sayısı bakımından işsizlik ödeneğine hak kazanmış olması gerekmektedir.

4447 Kanun'un 50'nci maddesine göre ise "Günlük işsizlik ödeneği, sigortalının son dört aylık prime esas kazançları dikkate alınarak hesaplanan günlük ortalama brüt kazancının yüzde kırkıdır. Bu şekilde hesaplanan işsizlik ödeneği miktarı, 4857 sayılı iş Kanununun 39'uncu maddesine göre onaltı yaşından büyük işçiler için uygulanan aylık asgari ücretin brüt tutarının yüzde seksenini geçemez (f.1)." Hizmet akdinin sona ermesinden önceki son 120 gün hizmet akdine tabi olanlardan, son üç yıl içinde: (a) 600 gün sigortalı olarak çalışıp işsizlik sigortası primi ödemiş olan sigortalı işsizlere 180 gün; (b) 900 gün sigortalı olarak çalışıp işsizlik sigortası primi ödemiş olan sigortalı işsizlere 240 gün; (c) 1080 gün sigortalı olarak çalışıp işsizlik sigortası primi ödemiş olan sigortalı işsizlere 300 gün süre ile işsizlik ödeneği verilir (f.2).

Anılan hükümler değerlendirildiğinde kısa çalışmaya başvuru konusunda sektörel bir ayrım yapılmadığı görülmektedir. Dolayısıyla spor kulüpleri de işveren olarak kısa çalışmaya ilişkin başvuru yapabilirler. Ancak burada dikkat edilmesi gereken konu ülkemizde uygulanan profesyonel - amatör ayrımıyla yakından ilgilidir. Ülkemizde profesyonel olarak uygulanan tek dal futbol olduğu için diğer spor dallarında spor kulüplerinin çalışanlarının kısa çalışma ödeneğinden faydalanmaları en azından 5510 sayılı Kanuna göre sigortalı sayılan, sporcu antrenör dışındaki diğer çalışanlar açısından mümkün olacaktır. Çünkü görüleceği üzere işçilerin (sporcu - antrenör) kısa çalışma ödeneğinden yararlanabilmesi için belirli süre çalışmış ve işsizlik sigortası ödemiş olması gerekmektedir. Amatör spor dallarındaki kulüplerin bu gerekleri yerine getirdiği söylenemez. Profesyonel liglerde mücadele eden kulüplerin futbolcu ve futbol antrenörlerinden, kısa çalışma ödeneği alma şartlarını sağlayanlar bu ödenekten faydalanabilir. Yukarıda izah ettiğimiz liglerin uzaması sonucu sözleşme süreleri uzamış sayılan futbolcu ve antrenörler, üç aya kadar bu ödenekten yararlanabilirler ${ }^{15}$. Şayet ligler bu

\footnotetext{
${ }^{14}$ Bkz. 4447 sayılı Kanun m.Ek.3, Geçici m.23, Geçici m.24, Geçici m.25.

15 Sadece sözleşmeleri uzamış sayılanlar değil, şartları uyan diğer kişiler de bu ödenekten faydalanır. Metinde makalenin konusu olduğu için süreleri uzamış futbolcu ve antrenörler zikredilmiştir.
} 
düzenlemedeki üç aylık süreden önce başlayacak olursa, ödeneklerden ligler başlayıncaya kadar faydalanabilirler.

Fesih Yasağı ve Ücretsiz İzin Uygulaması. 4857 sayılı Kanuna eklenen Geçici 10'uncu maddeyle işverenlerin fesih hakları geçici süre ile sınırlandııımıştır. Hükme göre, İş Kanunu kapsamında olup olmadığına bakılmaksızın her türlü iş veya hizmet sözleşmesi, Geçici 10'uncu maddenin yürürlüğe girdiği tarihten (16.04.2020) itibaren üç ay süreyle, işverenin haklı nedenle fesih hakkını düzenleyen İş K. 25'inci maddenin birinci fıkrasının (II) numaralı bendinde ve diğer kanunların ilgili hükümlerinde yer alan ahlak ve iyi niyet kurallarına uymayan haller ve benzeri sebepler dışında işveren tarafından feshedilemeyeceği hükme bağlanmıştır. Yani bu durumda işverenler, anılan süre boyunca ahlak ve iyi niyet kurallarına uymayan haller dışında işçilerin sözleşmelerini tek taraflı olarak sona erdiremeyeceklerdir. Bu durumda kulüpler; sporcu, antrenör ya da diğer kulüp çalışanlarının iş sözleşmelerini anılan haklı nedenler dışında sona erdiremeyeceklerdir. Şüphesiz spor federasyonlarının talimatlarına göre uzadığı varsayılan sözleşmelerle ilgili de bu hüküm geçerli olacaktır.

İş K. Geçici 10'un maddesinin ikinci fıkrasına göre ise bu maddenin yürürlüğe girdiği tarihten itibaren üç aylık süreyi geçmemek üzere işveren işçiyi tamamen veya kısmen ücretsiz izne ayırabilir. Bu madde kapsamında ücretsiz izne ayrımak, işçiye haklı nedene dayanarak sözleşmeyi fesih hakkı vermez. Maddeyle yürürlüğe girdiği tarih olan 16.04.2020'den 16.07.2020'ye kadar (hatta Cumhurbaşkanı tarafından süre uzatıırsa 16.10.2020'ye kadar) işverenlere işçiyi tamamen veya kısmen ücretsiz izne ayırma hakkı vermektedir. Bu süreçte sözleşmeler varlıklarını koruyacak ancak taraflar sözleşmeden kaynaklı yükümlülüklerini kısmen veya tamamen yerine getirmeyeceklerdir. Hatta madde metninde bu durumun mutlaka Covid-19 sebebine dayanma veya işverenin kısa çalışmaya başvurma şartı da bulunmamaktadır. Bu durumdaki işçiler için 4447 sayılı Işsizlik Sigortası Kanunu'nda ayrıca bir düzenleme yapılmıştır ${ }^{16}$. Son halde kulüplerin sporcuları veya antrenörleri üç aya kadar ücretsiz izne çıkarması mümkün müdür? Kanaatimizce kulüpler, liglere verilen ara boyunca sporcuları, antrenörleri ve diğer kulüp çalışanlarını ilgili düzenleme gereği ücretsiz izne çıkarabileceklerdir. Böyle bir durumda belirli süreli iş sözleşmelerinin ücretsiz izin süresi kadar uzayacağı düşünülebilir. Kanaatimizce ücretsiz izin süresi ne kadar uzun olursa olsun, uzamış sayılan sözleşmeler sezon biter bitmez sona erecektir. Yani örneğin 12.05.2020'de ücretsiz izne ayrılan ve normalde sözleşmesi 31.05.2020'de bitecek olan bir futbolcunun sözleşmesi, sezon 12 Haziran - 12 Temmuz arası oynanıp tamamlansa bile ücretsiz izin süresi kadar uzamaz, ligin tamamlandığı 12 Temmuz'da sona erer.

Bu intimalde de örneğin sporcu dipnotta belirtilen 4447 sayılı Kanun Geçici m.24'deki ücret desteklerinden faydalansa bile aylık ücretinin kalan kısmını kulüpten talep edemeyeceğini

\footnotetext{
${ }^{16}$ Bkz 4447 sayılı Kanun Geçici Madde 24 - (Ek:16/4/2020-7244/7 md.)

Bu maddenin yürürlüğe girdiği tarihte iş sözleşmesi bulunmakla birlikte 4857 sayılı Kanunun geçici 10 uncu maddesi uyarınca işveren tarafından ücretsiz izne ayrılan ve kısa çalışma ödeneğinden yararlanamayan işçiler ile 15/3/2020 tarihinden sonra 51 inci madde kapsamında iş sözleşmesi feshedilen ve bu Kanunun diğer hükümlerine göre işsizlik ödeneğinden yararlanamayan işçilere, herhangi bir sosyal güvenlik kuruluşundan yaşııık aylığı almamak kaydıyla ve 4857 sayılı Kanunun geçici 10 uncu maddesinde yer alan fesih yapılamayacak süreyi geçmemek üzere, bu süre içinde ücretsiz izinde bulundukları veya işsiz kaldıkları süre kadar, Fondan günlük 39,24 Türk lirası nakdi ücret desteği verilir. Yapılan ödemelerden damga vergisi hariç herhangi bir kesinti yapilamaz.

Birinci fıkra kapsamında ücretsiz izne ayrılarak nakdi ücret desteğinden yararlanan işçinin fiilen çalıştırıldığının tespiti halinde işverene, bu şekilde çalıştırılan her işçi ve çalıştırıldığı her ay için ayrı ayrı olmak üzere fiilin işlendiği tarihteki 4857 sayılı Kanunun 39 uncu maddesince belirlenen aylık brüt asgari ücret tutarında çalışma ve iş kurumu il müdürlüklerince idari para cezası uygulanır ve ödenen nakdi ücret desteği ödeme tarihinden itibaren işleyecek kanuni faizi ile birlikte işverenden tahsil edilir.

Bu madde kapsamında nakdi ücret desteğinden yararlananlardan 5510 sayılı Kanuna göre genel sağlık sigortalısı veya genel sağlık sigortalısının bakmakla yükümlü olduğu kişi kapsamına girmeyenler, aynı Kanunun 6oıncı maddesinin birinci fıkrasının (g) bendi kapsamında genel sağlık sigortalısı sayılırlar ve genel sağlık sigortasına ilişkin primleri Fondan karşılanır.

Bakanlık, nakdi ücret desteğine ilişkin ödeme usul ve esaslarını belirlemeye ve bu maddenin uygulanmasına ilişkin ortaya çıkabilecek tereddütleri gidermeye yetkilidir.
} 
düşünmekteyiz. Neticede işin görülmesi ve ücretin ödenmesi yükümlülükleri açısından temerrüt karşılıklıdır. Yine geçici 10'uncu maddenin izleyen fıkralarına göre de bu madde hükümlerine aykırı olarak iş sözleşmesini fesheden işveren veya işveren vekiline, sözleşmesi feshedilen her iş̧̧i için fiilin işlendiği tarihteki aylık brüt asgari ücret tutarında idari para cezası verilir. Cumhurbaşkanı birinci ve ikinci fıkrada yer alan üç aylık süreleri altı aya kadar uzatmaya yetkilidir. Son olarak bu intimalde kulüpler, ücretsiz izne ayırdıkları sporcu ve antrenörlere teknolojik araçlarla uzaktan antrenman vb uygulamaları da yaptıramayacaklardır. Çünkü kulüplerin ücret ödeme yükümlülüğü askıda olacağı gibi sporcuların da iş görme yükümlülüğü askıda olur.

\section{Sonuç}

Spor organizasyonları dünya çapında önemli bir çalışma alanıdır ve ilgiyle takip edilmektedir. Bu minvalde spor kulüplerinde çalışan sporcu ve antrenörlerin sözleşmeleri de her zaman ilgi çekici olmuştur. Bu sözleşmelerle ilgili olarak tartışılan konuların başında da söz konusu sözleşmelerin hukuki yönüdür. Şüphesiz Covid-19 salgını 2020 yılında dünya gündemine oturmuş ve birçok alanı olumsuz etkilemiştir. Spor sektörü de bundan nasibini almış, neredeyse spor faaliyetlerinin tümü belirsiz bir süre için durdurulmuştur. Bu durum müsabaka takvimlerinin de süresinde tamamlanamamasına yol açmış, belirli süreli iş (hizmet) sözleşmelerinin yaygın olduğu bu alanda soru işaretlerine sebep olmuştur. Çalışmamızda yaptığımız değerlendirme sonucunda şu kanaatlere varılmıştır.

- Bazı federasyonların düzenlemelerinde, sporcu ve antrenörlerin sözleşme sürelerinin uzamış sayılmasına ilişkin hükümler mevcutken, bazıların bu yönde bir hüküm yoktur.

- Spor federasyonlarının yasama kudreti bulunmamaktadır. Bulundukları ülkelerin hukukuna uymak zorunda oldukları gibi, yaptıkları düzenlemeler kanunlarla çatıştığında geçersizdir. Ancak Kanunlarla çatışmaya sebep olamayacak konularda ve faaliyet alanlarıyla ilgili düzenleme yapabilirler. Bununla birlikte, uluslararası federasyonlara üye olan bir federasyonun (Türkiye Futbol Federasyonu, Türkiye Basketbol Federasyonu gibi) uluslararası düzenlemelere uyum sağlama yükümlülüğü de göz ardı edilmemelidir. Ancak altını çizerek belirtmemiz gerekir ki buradaki tespitimiz durumun ulusal yargı organlarına sirayet edeceği durumlarla ilgilidir. Genellikle uluslararası transferlerde ve sözleşmelerle farklı tahkim organlarının görevli kıındığı yargılamalara ilişkindir. Böyle durumda genellikle uluslararası spor federasyonlarının düzenlemeleri ve ilgili tahkim organının içtihatları geçerli olacaktır.

- Uzamış sayılan sözleşmeler yeni bir sözleşme değil, eski sözleşmenin devamıdır. Sözleşmelerin uzamış sayılması konusunda bir ayrım yapılmalıdır. Küresel salgın gibi tüm uluslararası federasyonları ilgilendiren konularda sözleşmenin uzadığını kabul edilebilir. Ancak farklı sebeplerle (doğa olayları, ulusal salgın, terör vb. olaylar) ulusal federasyonları tekil olarak etkileyen durumlarda uzama süresinin makul olduğunda sözleşme uzamış sayılmalıdır. Bu duruma yönelik makul sürelerin uluslararası federasyonlarca tespiti isabetli olacaktır.

- Uluslararası spor federasyonlarının müsabaka takvimlerinin dünya çapında mevcut sezonların aynı zaman diliminde tamamlanıp, yeni sezonların benzer takvime ayarlanması durumunda tarafların mağduriyeti azalacaktır.

- Türk Hukukundaki kısa çalışma ve kısa çalışma ödeneği ile fesih yasağı ve ücretsiz izin uygulamaları spor kulüplerince de uygulanabilir.

\section{Kaynaklar}

Akyiğit, E. (2016). İş Hukuku. Ankara: Seçkin Yayıncılık.

Antalya O. G. ve Topuz M. (2019) Medeni Hukuk. İstanbul: Seçkin Yayıncılık. 
Baştürk, F. (2005). Teknik direktör ve antrenörlerin hukuki durumu. Legal iş ve Sosyal Güvenlik Hukuku Dergisi, Sayı:6, S-S.604

Baştürk, F. (2007). Iş Hukukunda Profesyonel Futbolcu. İstanbul: Beta Yayıncılık.

Baycık G. (2011). Iş̧ hukukunda yenilik doğuran haklar. Yayımlanmamış Doktora Tezi. Ankara Üniversitesi Sosyal Bilimler Enstitüsü.

Baykal F. H. (2007). Spor kuruluşlarının uluslararası hukuktaki yeri. Spor Hukuku Dersleri, (Eds) Kısmet Erkiner. İstanbul: Kadir Has Üniversitesi Yayınları.

Bozkurt Gümrükçüoğlu, Y. (2012). Belirli süreli iş sözleşmesi. Yayımlanmamış Doktora Tezi. İstanbul Kültür Üniversitesi Sosyal Bilimler Enstitüsü.

Çelik N., Caniklioğlu N. ve Canbolat T. (2018). Iş̧ Hukuku Dersleri. İstanbul: Beta Yayıncılık.

Demir F. (2016). İş Hukuku ve Uygulaması. İzmir: Albi Yayınları.

Demircioğlu M ve Centel T. (2016). Iş Hukuku. İstanbul: Beta Yayıncılık.

Deryal Y. (2011). Hukukun Temel Kavramları. Trabzon: Derya Kitabevi.

Esener T. (2008). Genel Hukuk Bilgisi. İstanbul: Alkım Yayınevi.

Eyrenci Ö., Taşkent S. ve Ulucan D. (2019). Bireysel İş Hukuku. İstanbul: Beta Yayıncılık.

Mollamahmutoğlu H., Astarlı M. ve Baysal U. (2018). Iş Hukuku Ders Kitabı: Bireysel iş Hukuku. Lykeion Yayıncılık: Ankara.

Narmanlıoğlu Ü. (2014). Ferdi işs Ilişkileri. İstanbul: Beta Yayıncılık.

Senyen-Kaplan T. E. (2018). Bireysel iş Hukuku. Ankara: Gazi Kitabevi.

Sümer H. H. (2018). iş Hukuku. Ankara: Seçkin Yayınları.

Süzek, S. (2018). iş Hukuku. Beta Yayıncılık: İstanbul.

Orhan, Ü. (2018). Sporda zorunlu tahkim kararlarının uygulanması, Legal Hukuk Dergisi, 16(192), 5563 5685 .

Orhan, Ü. (2019). Spor kulübü ve antrenör arasındaki sözleşmenin hukuki niteliği ve ana esasları, Legal iş ve Sosyal Güvenlik Hukuku Dergisi, 63, 993-1028.

Şakar, M. (2019). Iş̧ Hukuku ve Sosyal Güvenlik Hukuku. İstanbul: Beta Yayıncılık.

Tunçomağ, K. ve Centel T. (2018). iş Hukukunun Esasları. İstanbul: Beta Yayıncılık. 